\title{
Identifikasi Kromatografi Lapis Tipis Sudamala (Artemisia vulgaris L.)
}

Ira Arundina*, Theresia Indah Budhy S**, Muhammad Luthfi* dan Retno Indrawati*

*Departemen Biologi Oral, Fakultas Kedokteran Gigi Universitas Airlangga, Surabaya, Jawa Timur, Indonesia

${ }^{* *}$ Departemen Patologi Mulut dan Maksilofasial, Fakultas Kedokteran Gigi, Universitas Airlangga, Surabaya, Jawa Timur, Indonesia

*JI Mayjend Prof. Dr. Moestopo no. 47 Surabaya 60132, Indonesia; e-mail: arundinafkg@yahoo.com

\begin{abstract}
ABSTRAK
Karsinoma sel skuamosa rongga mulut merupakan jenis kanker yang paling sering ditemukan di rongga mulut. Faktor risiko utama terjadi keganasan di rongga mulut meliputi riwayat serta kebiasaan mengkonsumsi tembakau dan atau alkohol. Tanaman sudamala (Artemisia vulgaris L.) sering digunakan di masyarakat sebagai anti tumor pada organ pencernaan termasuk di rongga mulut, namun belum ada penelitian tentang bahan aktif yang berperan sebagai anti kanker di rongga mulut. Banyak didapatkan spesies dari genus Artemisia, sedangkan yang banyak tumbuh di Indonesia adalah spesies Artemisia vulgaris L. Tujuan penelitian ini adalah untuk menjelaskan identifikasi menggunakan Kromatografi Lapis Tipis (KLT) dari sudamala. Penelitian meliputi ekstraksi sudamala, identifikasi ekstrak sudamala, fraksinasi sudamala menggunakan Kromatografi Kolom Vakum dan identifikasi dari fraksi sudamala menggunakan Kromatografi Lapis Tipis (KLT). Ekstrak heksan sudamala yang dilakukan fraksinasi menggunakan n-heksan: etil asetat menghasilkan 11 fraksi. Fraksi $n$-heksan: etil asetat $(3: 7, \mathrm{v} / \mathrm{v})$ dari sudamala yang teridentifikasi menggunakan Kromatografi Lapis Tipis (KLT) mengandung terpenoid.
\end{abstract}

Maj Ked Gi Ind. Desember 2015; 1(2): 167 - 171

Kata Kunci: sudamala (Artemisia vulgaris L.), identifikasi, KLT, kanker rongga mulut

\begin{abstract}
Identification of Sudamala ( Artemisia vulgaris L.) Thin Layer Chromatography. Oral squamous cell carcinoma is the type of cancer which is most frequently found in oral cavity. The primary risk factor of malignancy in oral cavity includes the habit of consuming tobacco and or alcohol. The plant sudamala (Artemisia vulgaris L.) is often used in the community as anti-tumor in digestive organ, including in oral cavity. However, there have been no studies on active ingredients playing the role as anti-cancer in oral cavity. The species are mostly from the genus Artemisia, while those generally growing in Indonesia are the species Artemisia vulgaris L. The objective of this study is to explain the identification by TLC of sudamala. The study was sudamala extraction, identification of sudamala extract, sudamala fractionation with Vacuum Column Chromatography and identification of sudamala fractionation with TLC (Thin Layer Chromatography). The result shows that the fractionation using hexane extract resulted in 11 fractions of $n$-hexane: ethyl acetate. The conclusion of this study is that the fraction of $n$-hexane: ethyl acetate (3:7, v/v) sudamala (Artemisia vulgaris L.) identified contains terpenoids compounds.

Maj Ked Gi Ind. Desember 2015; 1(2): 167 - 171
\end{abstract}

Keywords: sudamala (Artemisia vulgaris L.), Identification, TLC, Oral Cancer

\section{PENDAHULUAN}

Kanker di rongga mulut merupakan salah satu dari kasus keganasan yang sering terjadi di seluruh dunia. Keganasan di rongga mulut dan orofaring ditemukan pada $3 \%$ dari sekitar satu juta lebih kasus keganasan yang terdeteksi selama satu tahun di Amerika Serikat. ${ }^{1}$ Insiden kanker rongga mulut di Indonesia cukup tinggi dan menempati urutan ke-6 dari seluruh kanker yang paling sering terjadi di dunia serta meningkat setiap tahunnya. Karsinoma Sel Skuamosa Rongga Mulut (KSSRM) berasal dari epitel mukosa mulut merupakan jenis kanker yang paling sering ditemukan di rongga mulut sekitar $90 \%{ }^{2}$ Faktor risiko utama terjadi keganasan di rongga mulut meliputi baik riwayat maupun kebiasaan mengkonsumsi tembakau, alkohol dan merokok. Benzopirene $(\mathrm{B}(\mathrm{a}) \mathrm{P})$ banyak terdapat dalam asap rokok, asap kendaraan, asap dari proses pembakaran bahan organik dan makanan yang diasap atau dipanggang. Benzopirene dapat menyebabkan mutasi gene, sehingga terjadi transformasi sel normal menjadi sel kanker. ${ }^{3}$ Beberapa penemuan tanaman obat yang menunjukkan efek farmakologis terhadap kanker, mendorong peneliti untuk melakukan eksplorasi bahan bioaktif dari tanaman. Dasar pemikiran penelitian ini, karena penggunaan tanaman obat untuk pengobatan kanker banyak 
digunakan di masyarakat dengan pertimbangan lebih aman, lebih murah dan mudah didapat. Tanaman sudamala (Artemisia vulgaris L.) sering digunakan di masyarakat sebagai anti tumor pada organ pencernaan termasuk di rongga mulut, namun belum ada penelitian tentang bahan aktif yang berperan sebagai anti kanker di rongga mulut.

Banyak didapatkan spesies dari genus Artemisia, yang tumbuh di Indonesia adalah spesies Artemisia vulgaris L. disebut sudamala dapat ditemukan tumbuh liar di ladang, hutan serta menyukai tanah yang lembab dan kaya humus. Sudamala banyak digunakan di masyarakat secara empiris berkhasiat anti radang, analgesik serta anti kanker pada saluran pencernaan dan payudara. ${ }^{4}$ Belum ada penelitian tentang Artemisia vulgaris L. sebagai anti kanker di rongga mulut, tetapi berdasarkan pendekatan etnofarmakologi dan kemotaksonomi maka dapat dibuktikan Artemisia vulgaris L. sebagai anti kanker di rongga mulut. Etnofarmakologi ialah pendekatan teoritik dengan memanfaatkan indikasi empirik penggunaan bahan tumbuhan sebagai obat, sedangkan kemotaksonomi dengan mencari tumbuhan lain dari suku yang mengandung zat sejenis yang terbukti aktif. Artemisinin merupakan bahan aktif isolat dari Artemisia annua L. yang mempunyai efek sebagai anti kanker. ${ }^{5}$ Artesunate derivat Artemisinin dari Artemisia annua L. juga terbukti mampu menghambat pertumbuhan sel kanker kolon. ${ }^{6}$ Ekstrak daun Artemisia argyi L. yang mengandung terpenoid dan flavonoid mampu menghambat karsinoma serviks dan mempunyai efek sitotoksik pada kultur sel He La. ${ }^{7}$ Beberapa senyawa alami telah dibuktikan mampu menghambat terjadinya interaksi antara karsinogen Benzopirene-7,8-diol-9,10-oxide dengan DNA melalui berbagai mekanisme. Senyawa-senyawa tersebut mempunyai gugus polifenol atau termasuk golongan flavonoid dan terpenoid yang banyak ditemukan di berbagai jenis tumbuhan. ${ }^{8}$

Penelitian ini, bertujuan untuk melakukan identifikasi menggunakan KLT (Kromatografi Lapis Tipis) terhadap fraksi $n$-heksana: etil asetat (3:7) dari sudamala (Artemisia vulgaris L.). Hasil penelitian dapat digunakan sebagai dasar pengembangan eksplorasi bahan aktif senyawa terpenoid dari sudamala pada penanggulangan kanker khususnya pada mukosa rongga mulut.

\section{METODE PENELITIAN}

Penelitian ini telah mendapat persetujuan dari komisi etik penelitian Fakultas Kedokteran Hewan Universitas Airlangga no: 015-KE. Bahan untuk penelitian adalah herba Artemisia vulgaris L. diperoleh dan dideterminasi di Balai Konservasi Tumbuhan Kebun Raya Purwodadi Pasuruan. Herba diambil dari tumbuhan yang berumur kirakira 24 bulan, tinggi tanaman sekitar $50 \mathrm{~cm}$, diambil dari ketinggian tempat $800 \mathrm{~m}$ di atas permukaan laut, diambil seluruh bagian tanaman di atas tanah, kemudian dibersihkan dari tumbuhan lain dan kotoran, dicuci, dikeringkan di udara terbuka tanpa sinar matahari langsung. Bahan yang sudah kering dihaluskan dengan mesin penggiling dan diayak dengan pengayak serbuk. Serbuk yang diperoleh disimpan dalam wadah yang tertutup rapat. Pembuatan bentuk serbuk agar pelarut lebih mudah kontak dengan bahan aktif tanaman sehingga ekstraksi lebih sempurna.

Pembuatan ekstrak dari herba Artemisia vulgaris $L$ dengan cara maserasi yaitu merendam serbuk Artemisia vulgaris $L$ dalam pelarut $n$-heksana selama 2 x 24 jam dalam bejana tertutup dibiarkan pada suhu kamar sambil sering diaduk. Penyaringan menggunakan buchner dan filtrat yang diperoleh ditampung, ampas dimaserasi lagi dengan pelarut yang baru. Maserasi dihentikan jika tidak ada warna ungu pada KLT setelah dilakukan orientasi kandungan terpenoid dengan KLT menggunakan fase gerak (eluen) $n$-heksana: etil asetat= 1:1 dan penampak noda anisaldehide asam sulfat. Hasil maserasi dikumpulkan, diuapkan dengan penguap putar pada tekanan rendah (rotavapor) sampai tidak ada penguapan lagi dan diperoleh massa ekstrak kental. Sisa pelarut dalam ekstrak kental diuapkan dalam lemari asam hasilnya disebut ekstrak $n$-heksana kering. ${ }^{9}$ Identifikasi ekstrak $n$-heksana Artemisia vulgaris L untuk mengetahui kandungan senyawa alkaloid, flavonoid, terpenoid, antrakinon dan polifenol secara KLT.

Dari ekstrak $n$-heksana yang telah teridentifikasi mengandung terpenoid dilakukan fraksinasi 
menggunakan kromatografi kolom vakum. Fase diam silika gel 60 (Merck) dimasukkan ke dalam sintered glass dalam keadaan kering. Pengisian dilakukan sampai setinggi $4-5 \mathrm{~cm}$ untuk kolom dengan diameter 2,5-3 cm. Ekstrak heksana dicampur dengan silika gel dan ditaburkan secara merata di atas permukaan silika gel dalam sintered glass yang telah dibasahi dengan pelarut. Pemadatan dalam silika gel 60 kemudian dilakukan eluasi menggunakan fase gerak $n$-heksan - etil asetat dengan peningkatan kepolaran. Fase gerak yang digunakan ialah $n$-heksana: etil asetat (10:0, $\mathrm{v} / \mathrm{v}), n$-heksana: etil asetat $(9: 1, \mathrm{v} / \mathrm{v}), n$-heksana: etil asetat $(8: 2, v / v), n$ - heksana: etil asetat $(7: 3, v / v)$, $n$-heksana: etil asetat $(6: 4, v / v), n$-heksana: etil asetat $(5: 5, \mathrm{v} / \mathrm{v}), n$-heksana: etil asetat $(4: 6, \mathrm{v} / \mathrm{v})$, $n$-heksana: etil asetat $(3: 7, v / v), n$-heksana: etil asetat $(2: 8, \mathrm{v} / \mathrm{v}), n$-heksana: etil asetat $(1: 9, \mathrm{v} / \mathrm{v})$, $n$-heksana: etil asetat $(0: 10, v / v)$. Untuk identifikasi digunakan Kromatografi Lapis Tipis menggunakan larutan pengembang $n$-heksana : etil asetat $=1: 2$ sebagai fase gerak, fase diam silika gel 60F 254 dan penampak noda anisaldehid - asam sulfat dengan pembanding Artemisinin (terpenoid) dari Sigma.

\section{HASIL PENELITIAN}

Dari $1 \mathrm{~kg}$ serbuk herba sudamala yang diekstraksi dengan cara maserasi bertahap sebanyak 6 kali menggunakan pelarut $n$-heksana, diperoleh ekstrak heksana seberat 88,4 gram. Hasil skrining fitokimia terhadap ekstrak herba sudamala dengan pelarut $n$-heksana diperoleh beberapa golongan senyawa yang memberikan hasil positif yaitu golongan senyawa terpenoid, flavonoid dan alkaloid.

Ekstrak heksana sudamala difraksinasi menggunakan kromatografi kolom vakum dengan fase diam silika gel dan fase gerak campuran $n$-heksana: etil asetat bergradien mulai dengan $n$-heksana: etil asetat $(10: 0, \mathrm{v} / \mathrm{v}), n$ - heksana: etil asetat $(9: 1, \mathrm{v} / \mathrm{v}), n$-heksana: etil asetat $(8: 2, \mathrm{v} / \mathrm{v}), n$ heksana: etil asetat $(7: 3, v / v), n$-heksana: etil asetat (6:4,v/v), $n$-heksana: etil asetat (5:5,v/v), $n$-heksana: etil asetat $(4: 6, \mathrm{v} / \mathrm{v}), n$-heksana: etil asetat $(3: 7, \mathrm{v} / \mathrm{v})$, $n$-heksana: etil asetat $(2: 8, \mathrm{v} / \mathrm{v}), n$-heksana: etil asetat $(1: 9, \mathrm{v} / \mathrm{v}), n$-heksana: etil asetat $(0: 10, \mathrm{v} / \mathrm{v})$.
Hasil diperoleh 1 fraksi yang telah diuji kemampuan anti kanker secara in vitro pada carcinoma cell line rongga mulut. ${ }^{10}$ Dari hasil uji persentase hambatan secara in vitro dan analisis probit didapatkan fraksi yang paling poten sebagai anti kanker ialah fraksi $n$-heksana: etil asetat $(3: 7, \mathrm{v} / \mathrm{v}) .^{10}$

Berdasarkan identifikasi menggunakan KLT menunjukkan pada fraksi $n$-heksana: etil asetat $(3: 7, \mathrm{v} / \mathrm{v})$ ada spot merah keunguan dengan penampak noda anisaldehide - asam sulfat, sesuai standart Artemisinin yang merupakan senyawa terpenoid. Noda pada fraksi tersebut yang sejajar dengan pembanding Artemisinin yang merupakan senyawa golongan terpenoid, mempunyai harga $\mathrm{Rf}=0,375$. Hal ini menunjukkan bahwa pada fraksi $n$-heksana: etil asetat $(3: 7, v / v)$ mengandung senyawa golongan terpenoid (Gambar 1).

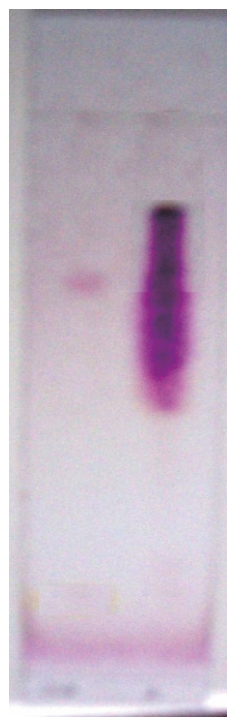

Gambar 1. Hasil KLT fraksi $n$-heksana: etil asetat (3:7, v/v)

\section{PEMBAHASAN}

Penelitian mengenai obat tradisional, khususnya yang bahannya berupa tanaman obat, terus berlangsung bahkan meningkat jumlahnya akhir-akhir ini. Meskipun demikian hingga kini, belum banyak hasil penelitian tanaman obat yang digunakan sebagai obat dalam pelayanan kesehatan. Obat yang dapat digunakan di masyarakat harus memenuhi persyaratan aman, bermanfaat dan sudah terstandardisasi. Tanaman sudamala sering digunakan di masyarakat sebagai 
anti tumor pada organ pencernaan termasuk di rongga mulut, namun belum ada penelitian ilmiah dan belum ditemukan bahan aktif yang berperan sebagai anti kanker di rongga mulut. Banyak didapatkan spesies dari genus Artemisia sedangkan yang banyak tumbuh di Indonesia adalah spesies Artemisia vulgaris L. Berdasarkan pendekatan etnofarmakologi dan kemotaksonomi dapat dibuktikan Artemisia vulgaris L. sebagai anti kanker. Etnofarmakologi ialah pendekatan teoritik dengan memanfaatkan indikasi empirik penggunaan bahan tumbuhan sebagai obat, sedangkan kemotaksonomi dengan mencari tumbuhan lain dari suku yang mengandung zat sejenis yang terbukti aktif. Pada penelitian ini proses ekstraksi Artemisia vulgaris $\mathrm{L}$ menggunakan teknik maserasi karena pemakaian alat sederhana dan tidak menggunakan panas sehingga menghindarkan senyawa di dalamnya terdegradasi oleh panas. Ekstraksi menggunakan $n$-heksana ditujukan terhadap isolasi senyawa terpenoid yang terkandung dalam Artemisia vulgaris $L$ yang memiliki aktivitas sebagai anti kanker. Sifat umum terpenoid yang non polar memerlukan pelarut non polar $n$-heksana sehingga diharapkan dapat menarik senyawa terpenoid. ${ }^{11}$ Hasil skrining fitokimia terhadap ekstrak herba sudamala dengan pelarut $n$-heksana diperoleh beberapa golongan senyawa yang memberikan hasil positif yaitu golongan senyawa terpenoid, flavonoid dan alkaloid. Terpenoid merupakan senyawa kimia yang berasal dari tanaman yang mengandung molekul isoprena (C5) dan yang kerangka karbonnya dibangun oleh penyambungan 2 atau lebih satuan C5. Terpenoid berdasar jumlah isoprena, terbagi menjadi senyawa golongan isoprena (C5), monoterpenoid (C10), seskuiterpenoid (C15), diterpenoid (C20), triterpenoid (C30), tetraterpenoid (C40) dan poliisoprena $(\mathrm{Cn})$. Terpenoid dapat menyebabkan sel tumor terpecah menjadi beberapa fragmen. ${ }^{11}$ Hal tersebut dapat menjelaskan salah satu mekanisme senyawa golongan terpenoid dalam menghancurkan sel kanker.

Berdasarkan identifikasi menggunakan Kromatografi Lapis Tipis (KLT) menunjukkan pada fraksi $n$-heksana: etil asetat $(3: 7, v / v)$ seluruh komponen hasil eluasi yang berasal dari totolan noda fraksi, terlihat merupakan spot merah keunguan dengan penampak noda anisaldehide-asam sulfat. Hal tersebut dibandingkan dengan warna merah keunguan sesuai dengan standart Artemisinin yang merupakan senyawa terpenoid. Hal tersebut menunjukkan bahwa seluruh komponen fraksi $n$-heksana: etil asetat $(3: 7, \mathrm{v} / \mathrm{v})$ Artemisia vulgaris $\mathrm{L}$ merupakan terpenoid.

Beberapa senyawa golongan terpenoid dari genus Artemisia yang sudah diteliti mempunyai khasiat anti kanker antara lain Artemisinin. Artemisinin termasuk golongan Sesquiterpene lactone dari Artemisia annua L. yang mampu menghambat sel kanker payudara secara in vitro melalui peningkatan aktivasi P53 wild. ${ }^{12}$ Artesunate derivat Artemisinin dari Artemisia annua L. terbukti mampu menghambat pertumbuhan sel kanker kolon. ${ }^{6}$

Ekstrak dari tanaman Artemisia pada umumnya mempunyai kemampuan sebagai anti inflamasi melalui hambatan terhadap enzim siklooksigenase $2 .{ }^{13}$ Artemisia vulgaris L. mempunyai efek anti inflamasi melalui hambatan enzim siklooksigenase $2 .{ }^{4}$ Jaceosidin bahan aktif dari Artemisia argyi diketahui dapat menghambat 12-o-tetradecanoylphorbol-13-acetate

(TPA) yang merupakan promotor tumor payudara melalui hambatan pada enzim siklooksigenase 2, MMP 9 dan ERK 1-2. ${ }^{14}$ Eupatilin bahan aktif dari Artemisia asiatica diketahui dapat menghambat 12-o-tetradecanoylphorbol-13-acetate (TPA) yang merupakan promotor tumor payudara melalui hambatan pada enzim siklooksigenase 2, NFKB dan Ras. ${ }^{15}$ Jaceosidin mempunyai daya hambat yang lebih besar daripada eupatilin terhadap 12-o-tetradecanoylphorbol-13-acetate (TPA) yang merupakan promotor tumor payudara. Jaceosidin juga dapat meningkatkan apoptosis sel kanker payudara melalui mekanisme peningkatan P53, Bax dan caspase $3 .{ }^{16}$ Mekanisme anti kanker dari Artemisia vulgaris L. dapat melalui efek hambatan terhadap enzim siklooksigenase 2 yang berperan mengkatalisis oksidasi dari $\mathrm{B}(\mathrm{a}) \mathrm{P}-7,8$ diol membentuk $\mathrm{B}(\mathrm{a}) \mathrm{P}-7,8-$ diol-9,10-oxide yang merupakan mutagenik karsinogen yang kuat dan reaktif. Benzopirene dapat menimbulkan mutasi p53 dan ras sehingga menimbulkan kanker kulit pada mencit. ${ }^{17}$ 


\section{KESIMPULAN}

Fraksi n-hexane: ethyl acetate (3: $7, \mathrm{v} / \mathrm{v})$ dari Sudamala (Artemisia vulgaris $L$ ) teridentifikasi secara KLT mengandung senyawa terpenoid.

\section{DAFTAR PUSTAKA}

1. Greenberg MS, Glick M. Burket's oral medicine diagnosis and treatment. Hamilton: BC Decker Inc. 2003; 194-201.

2. Pindborg JJ. Kanker dan prakanker rongga mulut. Jakarta. EGC. 2000; 1-138.

3. Cotran RS, Kumar V, Collins T. Pathologic basic of disease. $7^{\text {th }}$ ed. Philadelphia. WB Saunders Company. 2005; 260-325.

4. Padua LS, Bunyapraphatsara N, Lemmens RHMJ. Plant resources of south east asia. medicinal and poisonous plant jilid 1. Bogor Indonesia. 2000; 139-148.

5. Singh NP, Lai H. Selective toxicity of dihydroartemisinin and holotransferrin toward human breast cancer cells. Life Sciences. 2001; 70: 49-56.

6. Efferth T, Sauerbrey A, Olbrich A, Gebhart E. Molecular modes of action of artesunate in tumor cell lines. Molecular Pharmacology. 2003; 64(2): 382-394.

7. Dalimartha $\mathrm{S}$. Atlas tumbuhan obat indonesia jilid 1. Trubus Agriwidya. Jakarta. 2005; 7-12.

8. Yan Z, Subbaramaiah K, Camilli T, Zhang F, Tanabe T, McCaffrey TA, Dannenberg AJ, Weksler BB. Benzo(a)pyrene induces the transcription of cyclooxygenase-2 in vascular smooth muscle cells. J Biological Chemistry. 2000; 275(7): 4949-4955.

9. Elferaly, Farouk S, Elsohly, Hala N. Method for the isolation of artemisinin from artemisia annua. J Chrom. 1990; 355: 448-450.

10. Arundina I. Inhibitory effect of $n$-hexane: ethyl acetate fraction from artemisia vulgaris I. on cell culture of epithelial carcinoma of the mouth. Dental J. 2009; 42(1): 39-42.
11. Zhang S, Won YK, Ong CN, Shen HM. Anti cancer potential of sesquiterpene lactones bioactivity and molecular mechanisms. Curr Med Chem Anti Canc Agents. 2005; 5(3): 239249.

12. Singh NP, Lai $H$. Selective toxicity of dihydroartemisinin and holotransferrin toward human breast cancer cells. Life Sciences. 2001; 70: 49-56.

13. Kim DH, Na HK, Oh TY, Kim WB, Surh YJ. Eupatilin a pharmacologically active flavone derived from artemisia plants induces cell cycle arrest in ras transformed human mammary epithelial cells. Biochemical Pharmacology. 2004; 68: 1081-1087.

14. Jeong MA, Lee KW, Yoon DY, Lee HJ. Jaceosidin a pharmacologically active flavone derived from artemisia argyi inhibits phorbol ester induced upregulation of cox 2 and MMP 9 by blocking phosphorylation of ERK 1-2 in cultured human mammary epithelial cells. New York Academy of Sciences. 2007; 1095: 458-466.

15. Kim MJ, Kim DH, Na HK, Oh TY, Shin CY, Surh YJ. Eupatilin a pharmacologically active flavone derived from artemisia plants induces apoptosis in human gastric cancer cells. Journal Environ Pathol Toxicol Oncology. 2005; 24(4): 261-269.

16. Kim MJ, Kim DH, Lee KW, Yoon DY, Surh YJ. Jaceosidin induces apoptosis in ras transformed human breast epithelial cells through generation of reactive oxygen species. New York Academy of Sciences. 2007; 1095: 483-495.

17. Martin KR, Trempus $C$, Saulnier M, Kari FW, Barrett JC, French JE. Dietary N acetyl I-cysteine modulates benzo(a)pyrene induced skin tumors in cancer-prone p53 haploinsufficient Tg.Ac ( $v$ Ha-Ras) Mice. Carcinogenesis. 2001; 22(9): 1373-1378. 